Historic, archived document

Do not assume content reflects current scientific knowledge, policies, or practices. 




\section{WHAT THE NATIONAL FORESTS MEAN TO THE INTERMOUNTAIN REGION}

\section{WEALTH THAT COMES DOWN FROM THE MOUNTAINS}

The intermountain region is that vast, elevated basin between the Rocky Mountains on the east and the Sierra Nevada Range on the west and between the Salmon River on the north and the Grand Canyon of the Colorado River on the south.

The region is characterized by long, rough mountain ranges, small, fertile valleys, and great stretches of semiarid, desertlike plains. Settlement and economic development have been concentrated in relatively small areas within this wide territory and it would seem as if the fundamental wealth of the region were in these oasislike, irrigated valleys, and in the industrial cities and the mining camps. Land valuation helps to confirm this impression, rich, irrigated farming lands being worth from $\$ 100$ to $\$ 200$ or more per acre as compared with an assessed valuation of from $\$ 1$ to $\$ 10$ an acre for adjacent mountain lands. A careful study of underlying conditions, however, reveals the fact that a great deal of the wealth in the more flourishing sections comes directly or indirectly from the mountains; that it is the mountain masses, the sources of wood and water, which are the fountain heads of prosperity and development of the region. The lumber industry, the livestock industry, irrigated farming, water-power development, mining, and other economic activities all depend fundamentally on the resources drawn from the mountains and on the effect of the vegetative cover on their slopes.

Wood and water are what give life to the farms, the mines, and the cities; and the high mountain ranges are the chief contributors of these two fundamental necessities. The infinite number of small, low mountain ranges that break up the great plateau have not meant much to the development of the valley land because the resources which the mountains provide depend very largely upon the amount of rainfall they receive, which, in turn, is dependent in great measure upon their height. The mountains that have really counted in the upbuilding of the region are the high major masses, those which have enough rainfall to produce forests.

Out of approximately $35,000,000$ acres of mountain land in the region, valuable for timber and as the source of irrigation water, more than $30,000,000$ acres are now included within the national forests. The close relationship that exists between the national forests and the adjacent valleys and the dependence of these valleys on the resources furnished by the timbered mountains are indicated 
on the map (pp. 10-11), which shows that by far the greater part of the population of the intermountain region is crowded close to the mountain ranges covered by national-forest lands. In central Idaho, where there is a considerable population somewhat remote from national forests, the two are nevertheless closely linked by the Snake River, which receives the water needed by this population from the mountains within national forests.

\section{FORESTS AND INDUSTRIAL DEVELOPMENT}

In tracing the history of the function of mountain lands in the development of this region, it must be remembered that the areas which were only "mountain lands" for so many years are now national forests, and that the problems of these lands are now first and foremost national-forest problems. National-forest administration now deals with virtually all the resources which the mountains and mountain lands have furnished all through the years since white men came into this region and began its development.

\section{FUR TRADING}

EARLY HISTORY

After the explorers-Father Escalante and his party, who came up from what is now Arizona in 1776-77, and Lewis and Clark, who in 1804 entered a corner of this region in passing from what is now Montana into Idaho on their way westward-the first white men to invade the region were the fur traders. Andrew Henry, the first American to push the fur trade across the Continental Divide, built Henry's Fort in the fall of 1809 below the present town of St. Anthony and near what is now the Targhee National Forest, in eastern Idaho. He found the traffic unsatisfactory in that region, however, and retreated from his outpost the following spring. In 1811 the overland party of Astorians on their way to the Pacific Northwest left detachments at this fort with instructions to trap in the upper Snake River region. In 1819 Hudson Bay trappers from the north worked down through much of southern Idaho, and in 1824 large expeditions representing both the Hudson Bay Fur Co. from the north and Americans from the east came into the intermountain country. Gen. William H. Ashley, Jedediah Smith, Jim Bridger, and other famous frontiersmen were connected with the American party. After this year the whole intermountain region was well covered by trappers, both American and British.

In those days the trappers chiefly sought beaver fur, which brought the highest price, and worked mainly in the mountains. To them the valleys meant primarily easy avenues of travel or favorable spots in which to rendezvous and spend the winter. In the mountain forests the beaver swarmed on the creeks. The aspen tree, the favorite food of the beaver, was plentiful, and trappers throughout the region found the mountains a most satisfactory and profitable hunting ground.

\section{PRESENT OUTLOOK}

The glorious days of the fur trader have long since gone, trapping is now a much less picturesque pursuit, and the supply of fur-bearing animals has been depleted. Even now, however, the annual sale of 
skins is a matter of no small importance. Furthermore, the future promises more importance to this trade rather than less; for the beaver are increasing rapidly under protection. The mountain forests furnish ideal homes for these valuable animals, and forest preservation and protection assure the continuance of the beaver colonies amid natural conditions where they again thrive and produce annually hundreds of pelts of first quality and highest value. Not only the beaver, but many other kinds of fur-bearing animals (fig. 1), find homes in the timbered mountains, and in the future as in the past the fur trade will depend in a large measure upon the perpetuation of the mountain forests.

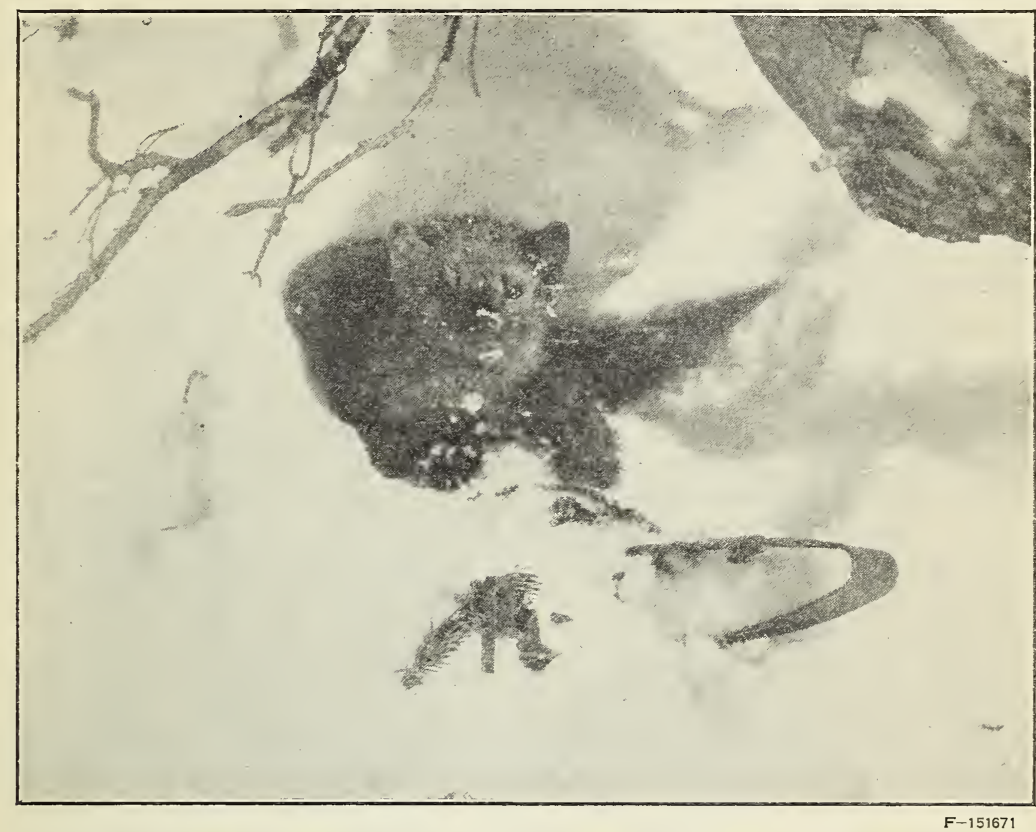

Figure 1.-Pine marten, a valuable fur-bearing animal, found only in the forests

\section{IRRIGATION}

THE MIORMON PIONEERS AND THE BEGINNING OF IRRIGATED FARMING

From about 1825 to 1847 the only industry of the intermountain region was that of the trapper and fur trader. In the summer of 1847, however, Mormon pioneers led by Brigham Young forced their way through the passes of the mountains that surround Salt Lake Valley and came down onto what was then a great sagebrushcovered flat. On July 23 the first advance guard drove their prairie schooners out of the mouth of Emigration Canyon to a halting place in what is now the center of Salt Lake City. That afternoon they unslung their plows, hitched up their teams, and started to turn a furrow. The soil was dry and baked and the attempt was unsuccessful, so turning aside the waters of the small stream now known as City Creek upon the sun-baked earth, they let it soak overnight 
and the next morning found no difficulty in plowing the land. With that first furrow began the irrigated agriculture of the intermountain region, which is the foundation of the greater part of the prosperity of the valleys to-day.

\section{PROSPERITY THROUGH IRRIGATION}

This prosperity is made possible only through the union of the fertile soil and the life-giving water from the mountains. Great depths of snow accumulate in the high ranges in the winter. Then through the spring and early summer the snow melts slowly, furnishing a great volume of water to the valley below. Later the earth yields its stored supplies through springs and wells. Three per cent of the $185,000,000$ acres within the intermountain region is cultivated-approximately 5,500,000 acres, of which 70 per cent or 3,850,000 acres, is irrigated. Each year this irrigated land produces crops worth approximately $\$ 174,000,000$.

\section{RELATION OF FORESTS TO WATER FLOW}

In a sense it is true that this water resource is so closely related to the climate and the characteristics of all mountains that man can never destroy it nor forests influence it. As long as the mountains stand, their cold heights will continue to accumulate great masses of snow, which the summer sun will melt and send down to the farms. Summer storms will continue to gather around the mountain crests, adding to the flow of the canyon streams. The amount of water which falls in the mountains can not be changed essentially by man. Nevertheless, man can do a great deal to determine whether the water shall flow gradually to the valleys and build up the farms and industries there or rush down in floods to destroy the very prosperity it might build up.

If the mountain vegetation is removed by fire, by destructive lumbering, by excessive grazing, or by any other means, erosion and floods follow. Showers cut the unprotected earth away and make steep-sided channels through which even the normal spring freshets from the gently melting snow rush with great violence, carrying along mud, gravel, and stone, clogging irrigation ditches and canals, filling reservoirs, and doing much damage. With the heavier storms of midsummer, destruction comes out of the mountains in the form of floods, carrying great bowlders, whole trees, and tons of earth, rock, and gravel, to spread over the farm lands in the valleys below. These storms destroy irrigation works, bridges, highways, and portions of towns. They even involve the loss of human life. In 1923, for example, floods from a half hour's thunderstorm in northern Utah did damage in excess of $\$ 150,000$ to fields and towns and killed nine persons. In this same region, severe floods occurred again in 1930 destroying ranches, homes, highways, and stretches of railroads.

Even partial destruction of the vegetation on the mountains (not to be confused with scientific harvesting of timber and forage crops as conducted on national forests which insures protection of the watersheds) means long-continued losses that amount to a great deal in the aggregate. The retaining of dams and great reservoirs becomes impossible on streams subject to floods and carrying great 
masses of débris; for, though the construction may be strong enough to withstand the rush of flood waters, the capacity of the reservoir is reduced with every freshet, and presently the reservoir is full of iiseless earth and rock instead of valuable water. Many small reservoirs throughout the intermountain region, now useless, bear silent witness to this fact.

There is also the item of time which might be put to productive use but is wasted each year in ridding the canals of their great accumulation of silt and sand. In some places the disposal of these accumulations has become a serious problem. On the irrigation project served by the Elephant Butte storage dam in New Mexico, enormous quantities of sand washed into the river from arroyos cause difficulty and great expense in keeping the canals free of sand accumulations.

SEASONAL VARIATION IN THE VALUE OF WATER TO CROPS

Less spectacular, but nevertheless real and very great is the loss in effectiveness of the water when it comes down all at once early in the season and then rapidly dwindles away through the summer. Studies made at the Utah Agricultural Experiment Station in regard to the duty of water, which are showing how to make the available irrigation water go farthest in the production of crops, have indicated that nearly every crop needs later water-that is, water through midsummer. Midsummer water is of much more value than a superabundance at the time of the spring freshets. Irrigation with early water alone frequently results in yields scarcely greater than those produced in the same neighborhood by dry farming.

Through the destruction of watershed cover, early melting of the snow is encouraged; the snowdrifts, instead of lying in the shade of the trees to melt slowly as late as July, are exposed to the full heat of the sun and rapidly disintegrate during the spring. Also, along with the processes that destroy trees and vegetation on the mountain comes the compacting of soil, which lessens its ability to absorb water. Hence surface run-off increases, spring freshets are intensified, and the flow of springs, which furnishes the late water in many of the streams, is decreased. Thus, although the total run-off is actually increased, it is far less useful and may prove dangerously destructive.

EFFECT OF WATER SUPPLY ON LAND VALUES

In the intermountain region the total value of farm land amounts to approximately $\$ 785,000,000$. By far the greater part of this value lies in the irrigated lands rather than in dry-farm areas and pastures. The water for irrigation comes almost entirely from mountains included in the national forests, which cover approximately $30,000,000$ acres of the intermountain region. Were the water taken from the irrigated lands, their value would decrease tremendously, for in some cases they would then be valuable only for grazing. Most of the land now irrigated would be unprofitable as dry-farm land. It would be difficult to estimate accurately the actual money value added to the farm lands of the region as the result of irrigation, but it is probable that the amount would reach more than 80 per cent of 
the total value of the land at present, or about one-half billion dollars. About 20,000,000 acres of the intermountain region is semibarren and $154,000.000$ acres, or 84 per cent, is valuable for its native crops of timber and forage.

\section{VALUE OF WATERSHED PROTECTION AS A FLOOD PREVENTIVE}

The effect of watershed protection on floods is shown by an experience which the town of Manti, in central Utah, passed through about 1904 or 1905 , when the watershed had been subjected to overgrazing and fires. Floods were extremely frequent and destructive, rushing out of the canyon above the town and doing great damage not only to the town itself but also to the fertile fields located on the alluvial fan at the mouth of the canyon. Damage estimated as high as $\$ 125,000$ was done in a few years. Conditions got so bad that some of the more pessimistic talked seriously of moving away and abandoning the town, because they believed that it was destined to be

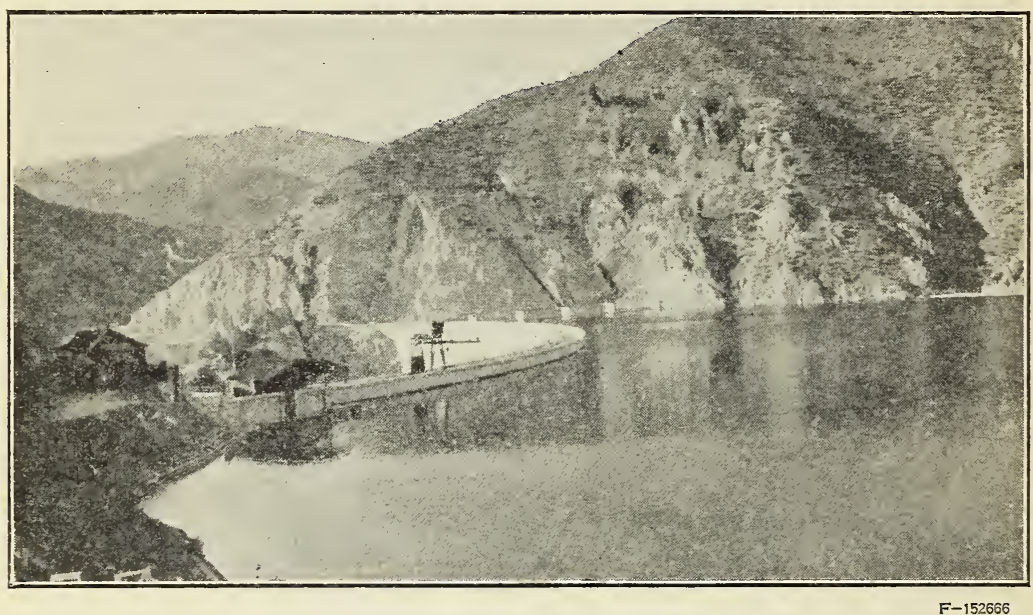

Figure 2.-Behind the Arrowrock dam on the Boise River, Idaho. The Boise River rises on national-forest land

forever subject to destructive floods and that prosperity could never exist there. After the creation of the Manti National Forest, in 1904 , the watershed was carefully protected from fires, overgrazing, and other destructive use. As a result Manti Canyon is singularly free from floods at the present time. The water flow is even, the town is prosperous.

City Creek, which discharges out of a rough and precipitous canyon into the very heart of Salt Lake City, has been protected for many years from all forms of use as a precautionary measure. In 1923 this canyon was undoubtedly subject to as heavy a rainfall as Farmington Canyon, a short distance north, from which issued a destructive flood. If such a flood had come out of City Creek the property loss would have been enormous, but the stream rose only about 4 inches. Watershed protection has a very real value in dollars and cents. 
THE LUMBER INDUSTRY

EARLY HISTORY

Hardly were the Mormon pioneers established in Salt Lake Valley when there came an insistent demand for wood for houses, barns, furniture, fuel, and many other purposes. The rush of gold seeker's to California in 1849 brought a boom to the region, and more and more lumber was needed. The mountains close at hand were the only source available.

Many stories are told of how completely the native forests were made to supply the needs of the early pioneers. The willows along the creeks furnished charcoal for gunpowder. The knotted and stunted mountain mahogany that grows in the crevices of rocks furnished excellent fuel, and from its extremely hard wood were made such articles as drumsticks and flutes. At a later date the cottonwood along the canyon bottoms and the aspen from the mountains in the vicinity of Salt Lake City were used in conjunction with rags, for the manufacture of paper upon which the Deseret News was for many years printed. To-day, old stumps on the most rugged parts of the mountains close to Salt Lake City and other early settlements tell better than words how tremendously valuable the conifers were for lumber and how the pioneers searched out timber in places where a modern logger would consider it unprofitable to go.

In 1865 gold was discovered in Boise Basin, and the rush to that region started a demand for lumber there. Timber was vastly more plentiful in Idaho than near the Mormon settlements. In the early days a small lumber industry began, which has continued to grow till the present time. In Utah and Nevada conditions were different. As soon as railroad connections with California and the Northwest were established, lumber from the coast came into use on account of both its higher quality and its lower price, for by that time the most accessible stands in the intermountain States had become greatly depleted by the excessive cutting of earlier years.

\section{PRODUCTION}

At the present time privately owned timberlands furnish the bulk of the timber cut in the intermountain region. Of the annual cut of approximately $165,000,000$ feet, the national forests of the intermountain region supplied $75,000,000$ feet in $1925,66,000,000$ feet in 1926, 51,000,000 feet in 1927, and 64,000,000 feet in 1928 and in 1929 .

Large lumbering operations are developing in the stands of western yellow pine and Douglas fir in western Idaho and there is an increasing use of lodgepole pine railroad ties from the forests of eastern Idaho and western Wyoming.

\section{TIMBER RESOURCES OF THE INTERMOUNTAIN NATIONAL FORESTS}

The national forests of the intermountain region contain approximately $48,000,000,000$ board feet of mature timber, of which approximately $12,000,000,000$, are Douglas fir, often known to the logger as "red pine," found chiefly in the forests of western Idaho, but extending over the entire region. Eleven billion board feet are western

$11773^{\circ}-30 \longrightarrow 2$ 
yellow pine, which occurs in large stands in western Idaho and southern Utah and on the Kaibab Plateau in northern Arizona. The lodgepole pine, of which there is more than 9,000,000,000 board feet, is found throughout the higher mountains of central and eastern Idaho and in large stands through western Wyoming and the Uintah Mountains of northern Utah. Engelmann spruce, of which the intermountain region has about $6,000,000,000$ board feet, is found throughout the entire region on the higher mountains, where it grows to timber line. Large stands are found in the Idaho National Forest in western Idaho, in the Ashley National Forest among the high Uintah Mountains, and in the Powell National Forest, on the high Aquarius Plateau of south Utah. Alpine fir, of which the forests of the intermountain district have more than $2,000,000,000$ board feet, is an associate of Engelmann spruce, having at present only a secondary commercial value. Other species, making up about $3,000,000,000$ board feet, include larch found in western Idaho, limber pine, a tree of high altitudes, especially common in Nevada, blue spruce, white fir, known in Utah as black balsam, and others of even rarer occurrence. There are also large areas of aspen timber, especially throughout Utah. Aspen is generally unsuitable for saw timber, but the national forests of this region contain nearly $11,000,000$ cords of this wood suitable for use in the manufacture of such articles as paper, matches, excelsior, and small boxes.

\section{HOW TIMBER IS CUT ON THE NATIONAL FORESTS}

The national forests are being managed in such a way as markedly to increase their productivity. In order to permit the development of a stable timber business, cutting will never be allowed to exceed the annual growth. The growth at present is estimated to be about $48,000,000$ board feet a year, a rate far below that which may ultimately be obtained under proper management. Many of the present stands are old or overmature and are producing little in the way of new growth, and others are so open that despite the rapid growth of individual trees not much is produced. It is probable, though, that ultimately the national forests of the intermountain region will be in a position to supply not only all of the $300,000,000$ board feet which the region is now estimated to consume annually but nearly three times that amount.

The timber resources of the forests are conserved by the requirement that all salable timber shall be marked or designated for cutting, before lumbering operations are begun and that certain precautions in the way of protecting young growth and removing slash be observed. In a region where the fire risk is great, slash is burned; otherwise it is either spread on the ground or, as in the case of some lodgepole pine stands in regions of low fire hazard, branches are left on the tops of trees where they fall so that the needles will drop off and decompose quickly. A forest expert selects the ripe timber and whatever other trees it is desirable to have removed, from the point of view of the forest's productivity and welfare, and after public advertisement, if $\$ 500$ worth of timber or more is to be disposed of, sale is made to the highest responsible bidder. Carefully planned inspection assures full performance of contract agreements. 
THE INCREASING IMPORTANCE OF NATIVE TIMBER

In the past it has been cheaper to get lumber from California and the Northwest than to utilize native timber (fig. 3), but now the whole Nation is looking to that limited region for much of its lumber. Higher prices for coast lumber will have a tendency to make the local timber of southern Idaho, Utah, and Nevada gradually come back into its own and occupy the important place it deserves in the economic life of the region. At present it is far too easy to underestimate the immense value of timber resources in the region. It is true that the timber is difficult to reach, nevertheless, it is capable of wide use, and as time goes on it is destined to replace much of the timber brought in from other regions. The railroads have already turned to local stands for their ties, and the mining industry looks to local forests for its mine props, frequently using trees which, on account of their size or quality, are not suitable for any other purpose.

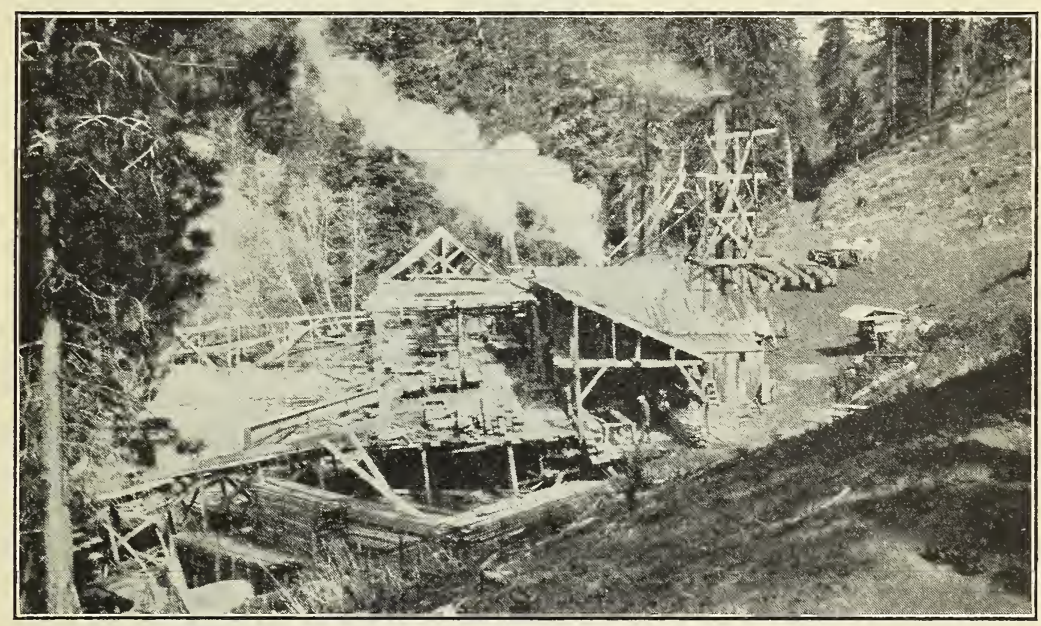

FigURE 3.- Small sawmill, characteristic of the intermountain region, cutting lumber for local trade

An incident connected with the Targhee National Forest may be referred to as typifying the change in attitude toward the value of timber on the national forests of this region, which has come about during the past 20 years. In 1905 some of the land which has since become part of the Targhee National Forest was being considered for inclusion in the forest. Its inclusion was urged by one of the prominent men of the region on the score that "the entire region supports no industry but grazing *** " and that "they (the lands) are not valuable for lumber but are exceedingly valuable to protect the very important streams * * *." Mention was also made of the very limited amount of merchantable timber on the land, most of it consisting of "inferior lodgepole pine, with occasional bodies of red fir." In 1928, from the forests consisting of such lands as this, sales of lumber reached a total of $63,600,000$ board feet, having a stumpage value of $\$ 127,258$. This was possible 


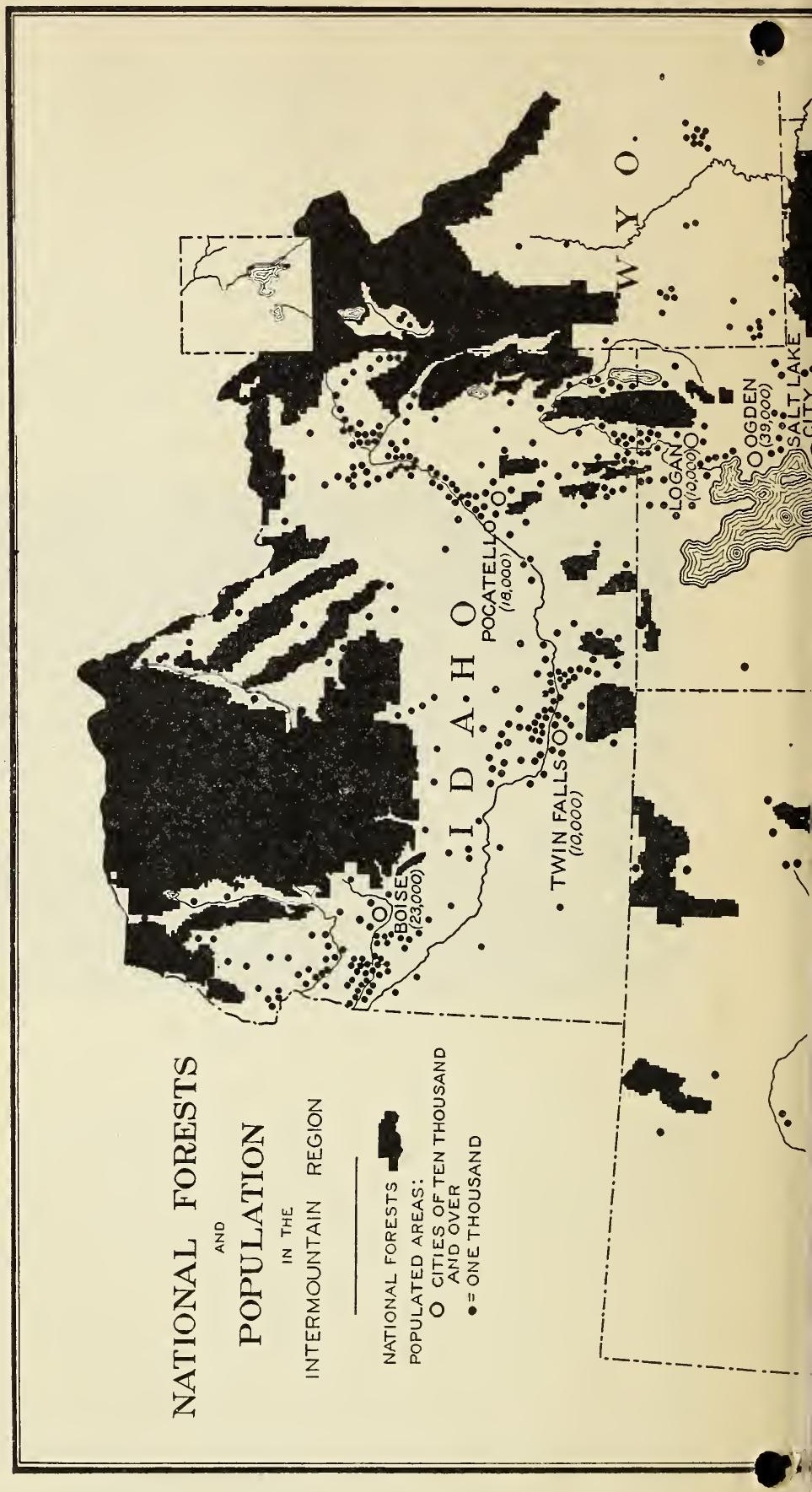





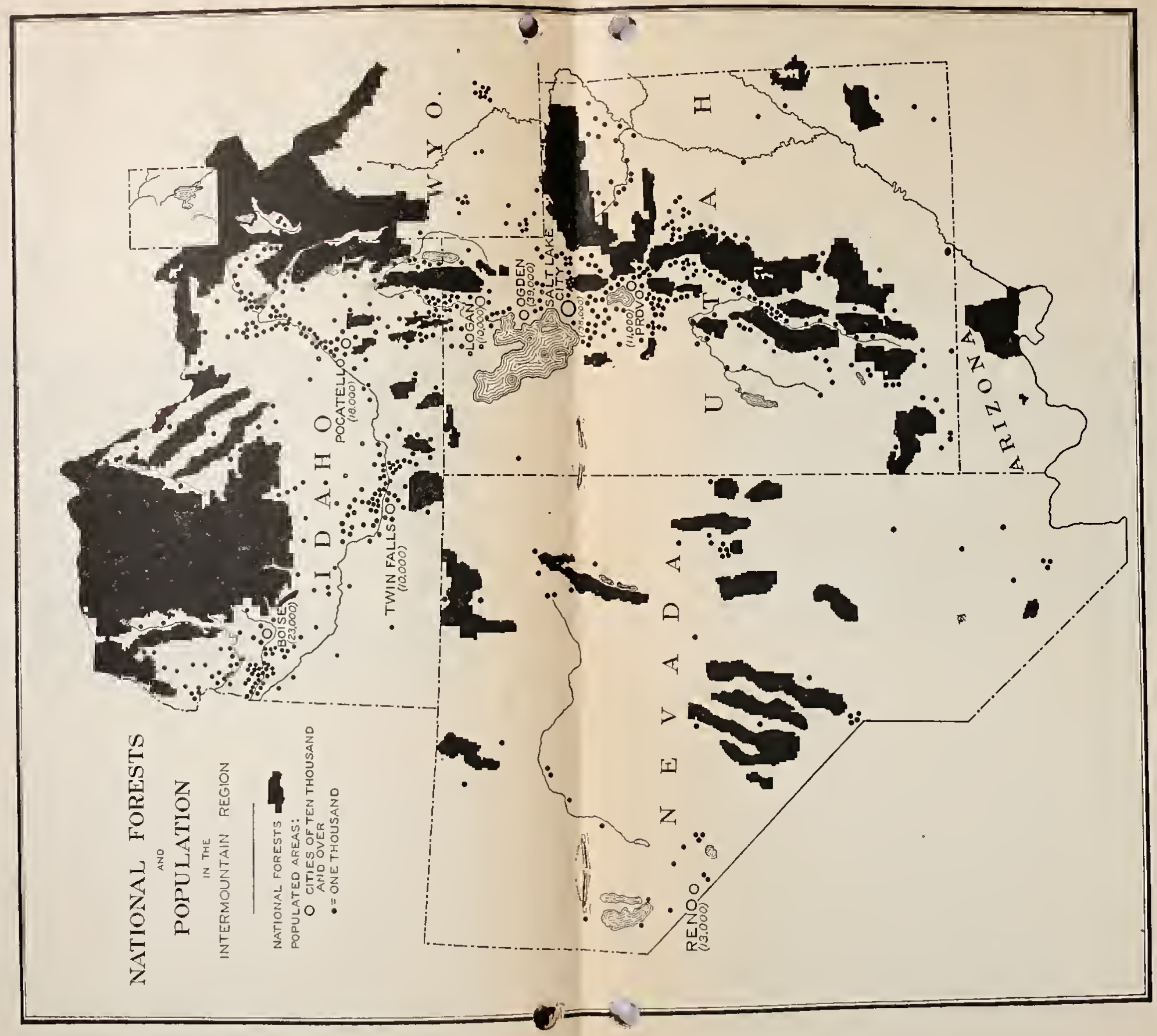


not because this amount of timber had grown during the past 23 years, but because of the striking revision that had taken place since 1905 in the idea of what timber is merchantable.

\section{THE LIVESTOCK INDUSTRY}

EARLY CONDITIONS ON THE RANGE

The earliest settlers in the intermountain region brought with them their horses, cows, and other domestic animals. For a long time they kept their stock on the ranches, a precaution necessary because of the danger from Indians. As the Indian menace abated and finally became negligible-about 1870 in Utah and rather later in Idaho-the settlers began to turn their cattle out into the adjacent mountain lands during the summer season, rounding them up in the fall. With the opening of these public grazing areas the sheep industry became increasingly important, and the sheep herds spread through the mountains. In Utah and Nevada, where the mountain range lands were not distant from settlements, the livestock business became very intensive, and the ranges were used by a great many more stock than was good for them. In Idaho, where, in general, settlement was more gradual, the number of stock was much smaller in proportion to the mountain areas than in Utah, and such heavy utilization of the range did not generally occur.

- WHAT THE FOREST LANDS MEAN TO THE LIVESTOCK INDUSTRY

All through the region the mountain ranges have contributed immensely to the prosperity of the livestock industry, allowing it to grow much more than it possibly could if it were limited all summer long to the valley lands in the vicinity of the ranches. The latter course would necessitate the maintenance of much larger pasture lands, which in turn would mean less land for the much more remunerative use of producing cultivated crops. Upon the national forests of this region, which include a large part but not all of the summer-grazing lands, 343,510 cattle and horses and 2.576 .000 sheep were grazed in 1929, not counting animals under 6 months old. Allowing for this omission, it appears that about onethird the cattle and one-half the sheep in the intermountain region summer upon national-forest range. (Fig. 4.) Horses are, of course, very generally kept about ranches, and consequently the national forests support only about 5 per cent of the total.

The continued prosperity of this tremendous livestock business, which produces in the intermountain region over $\$ 50,000,000$ annually, can be maintained only by proper management of the stock on the range. Individual initiative and a desire to expand business inevitably lead to the crowding and overstocking of any public ranges the use of which is not regulated. At the time the national forests were created, many of the mountain forests of Utah had already reached this condition. Range wars and unregulated competition were ruining the range, while innumerable fires "to improve the feed "were playing their destructive rôle. Something had already been done in the way of fire prevention by the Interior Department; but as soon as the national forests were placed under the adminis- 
tration of the Department of Agriculture, steps were ererywhere taken to apply a system of management and fire suppression, which aimed to conserve the forage and eventually restore the productivity and stock-carrying capacity of the ranges. The numbers of stock were gradually reduced where there were too many, the ranges were divided into different allotments for different owners, and the whole summer stock-raising business was placed upon an orderly basis under Federal control.

\section{DANGERS OF OVERGRAZING}

Unregulated grazing has a far-reaching effect in this region, for it not only means disaster to the livestock industry itself through the depletion of the very range necessary to its prosperity, but also threatens the agricultural prosperity of the valleys through the

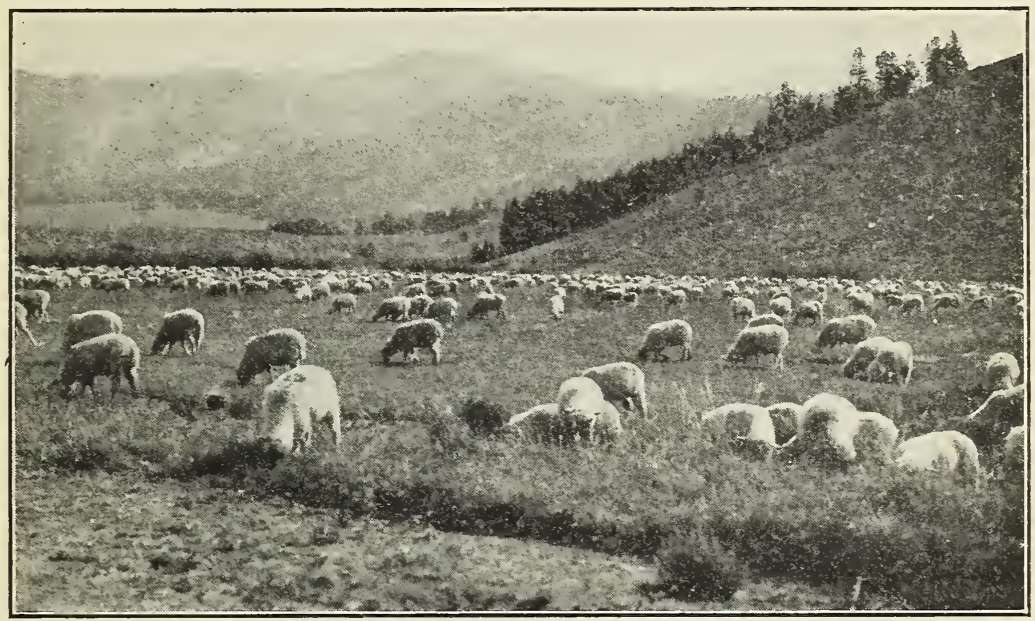

FIGURE 4.- Sheep grazing within a national forest

F-164034

destruction of the watershed cover and subsequent erosion of the top soil that is essential for a good vegetative cover. (Fig. 5.) Furthermore, overgrazing threatens the continuation of the timber stands; tiny trees 1 or 2 years old may be trampled to death by the cattle and sheep or nibbled and destroyed when very intensive grazing forces the stock to eat every green thing on the range.

FOREST MANAGEMENT AS RELATED TO LIVESTOCK

At present the range livestock industry is settled upon a basis firmer than at any time in its history. Stock on the national forests have been reduced where necessary, so that no more are run on the range than can be maintained there year after year without depleting the range resources. At the same time inaccessible regions have been opened by the construction of trails, bridges, and other improvements. Range which was useless on account of lack of water has been made available for large numbers of livestock through the 
development of small springs and seeps. Certain forests had their flocks and herds reduced as much as 30 per cent for certain classes of livestock in the past two decades, to correlate the numbers grazed with the capacity of the ranges for feeding them on a long-continued and profitable basis.

The wise management of the national-forest lands means everything to the livestock business. Without it, summer grazing in the mountains, the backbone of the livestock industry of the intermountain region, would be lost.

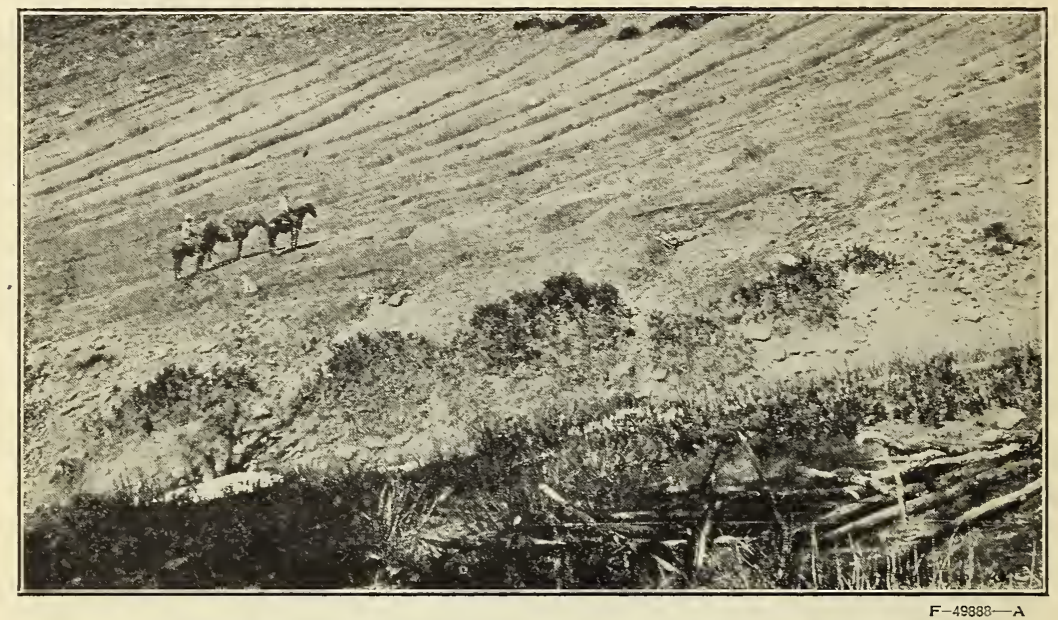

FIGURE 5.-The result of overgrazing; forage and watershed protection destroyed

\section{HYDROELECTRIC POWER}

EXTENT OF DEVELOPMENT

One of the characteristics of the intermountain region is the prevalence of electric light and power in all the small towns in the vicinity of the mountains. The secret, of course, lies in the abundance of water power derired from the never-failing streams emerging from the canyons. (Fig. 6.) There are 107 power plants driven by water power in the intermountain region, and Utah alone has 69. The development of this resource has scarcely begun. Within the intermountain region it has been estimated that from $2,750,000$ to $5,250,000$ horsepower may be developed. Of this amount approximately half is located within the national forests and the remainder upon the larger rivers which have their origin in the high mountain lands covered by the same forests.

\section{DEPENDENCE ON FOREST COVER}

Like irrigation projects, hydroelectric development is greatly hampered, if not impossible, on mud-laden, rock-carrying streams, subject to floods every spring and after the summer thunderstorms that break the periods of low water and drought. Rivers, like the Snake, Bear, and others that drain large areas are, of course, not 
so subject to difficulties of this kind as are the small streams running in short, steep canyons, where a single fire or local overgrazing may so destroy water-shed values that economical hydroelectric power production becomes problematical.

In a single storm in 1923, which brought floods down both Willard and Farmington Canyons, the two small power plants at these points were put out of commission by the rush of bowlders and rocks borne along on the face of the floods.

Devastation of the mountains would check the hydroelectric development of the intermountain region. Even moderate devastation, entirely within the bounds of possibility, would mean difficult and costly operation for a vast number of small plants scattered throughout the region and serving a multitude of small, isolated communities. Small electric plants, while they do a business which may appear

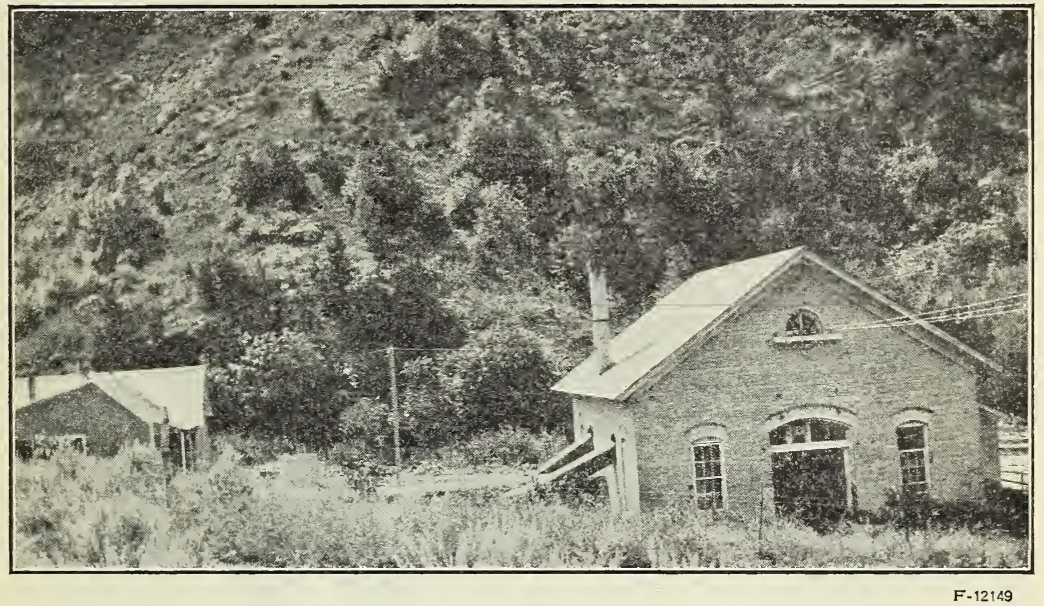

Figure 6.-Municipal power plant in Logan Canyon, Cache National Forest, Utah

insignificant in comparison with the great power plants on the large rivers, play an important part in the life of the intermountain region, supplying electric current to remote towns and villages and giving them such modern conveniences as electric lights, washing machines, irons, vacuum cleaners, and motion pictures.

\section{RECREATIONAL USE OF THE INTERMOUNTAIN NATIONAL FORESTS}

\section{WILD-LIFE RESOURCES OF THE FORESTS}

Who can state the value in dollars and cents of the fish to the fisherman, or the wild game to the hunter? Scattered through the national forests in this intermountain region are some 125,000 deer, about 30,000 of them in the Kaibab Forest in northern Arizona. The Teton is famous for its elk, and it is estimated that close to 17,000 of these splendid animals range upon the forest. (Fig. 7.) Many have been transplanted and at the present time elk are scattered over the greater part of the national-forest area of the region. One herd 
of elk planted on the section of the Uinta Forest centering around Mount Nebo is estimated at approximately 650 head. Moose are rare, being limited to about 2,500 ranging close to Yellowstone National Park upon the Teton and Targhee Forests. Mountain goats, also, are rare. Probably some 1,300 of them dwell among the high,

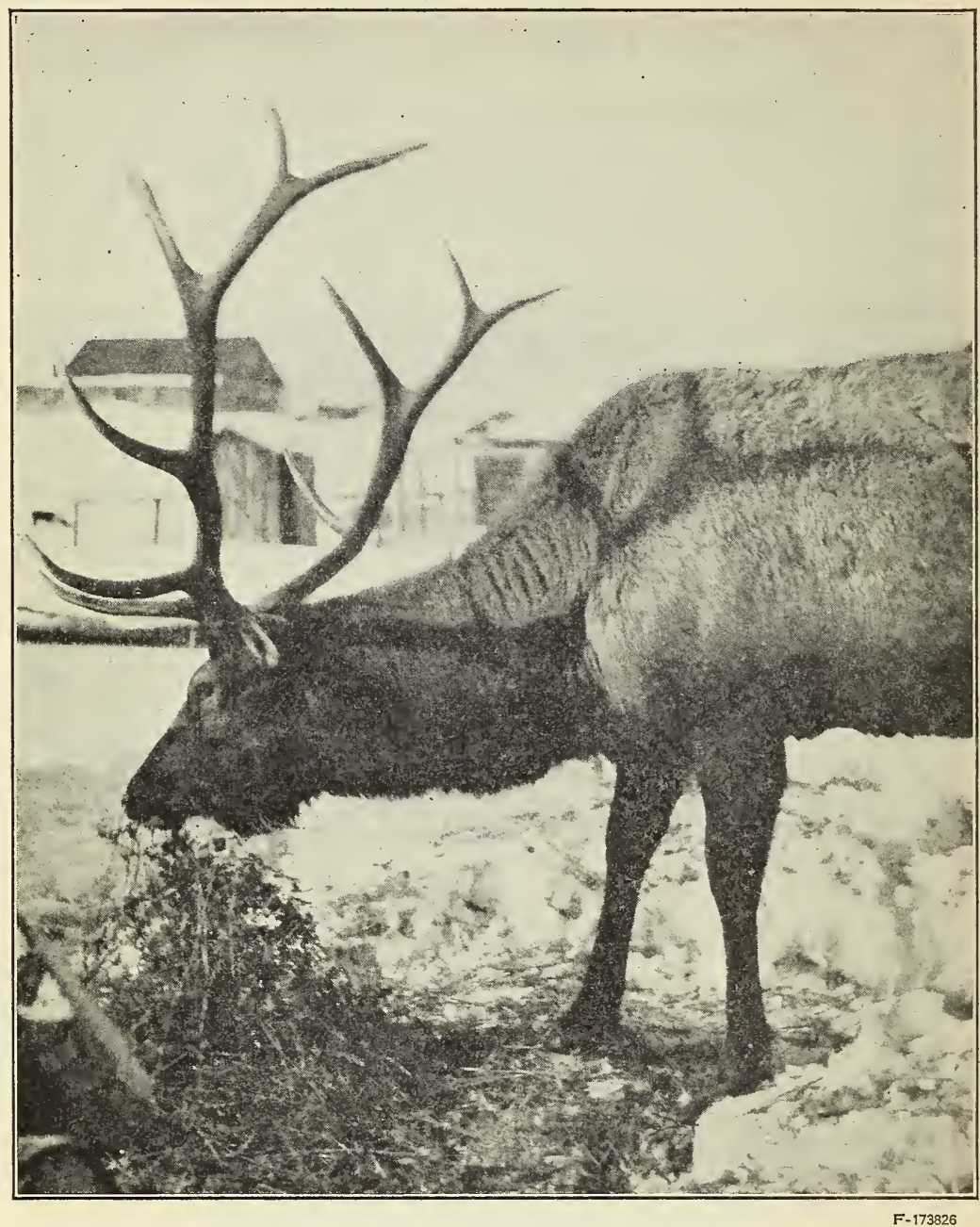

FIGURE 7.-Elk wintering in Jackson Hole. Much of the elk mountain range is within the Teton National Forest

almost inaccessible mountain peaks of central Idaho. Mountain sheep are about as numerous, but are scattered very widely over the forests of the region.

While the management and control measures affecting this game rests with the States, the Forest Service cooperates heartily with the State officials in enforcing the game laws, planting fish (fig. 8), 
and preventing trespass upon areas set aside for game. Within the national forests of this region are 43 State and Federal game refuges comprising 6,027,280 acres. In addition the Forest Service itself has set aside over 900,000 acres primarily for the production of game.

Forest fires, destructive lumbering, and overgrazing would spell ruin to these wild-life resources. The maintenance of the forest assures their preservation.

\section{IMPROVEMENTS}

Recreational use of the forests has been systematized by setting aside public camp grounds and furnishing them with conveniences, by leasing at nominal rentals summer home and camp sites, and reserving special scenic vantage points for the enjoyment of all the

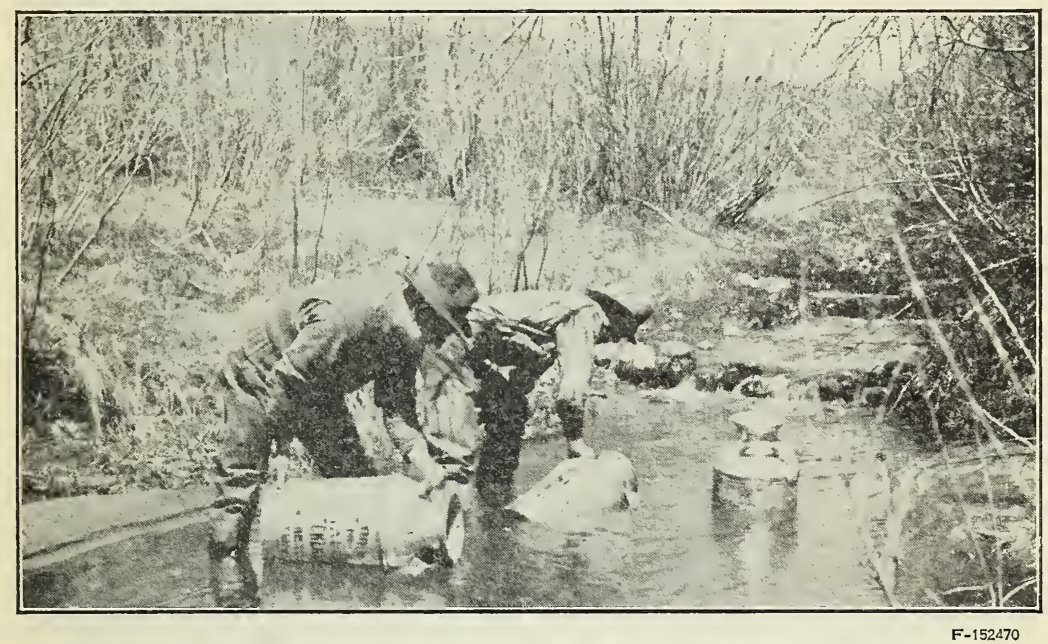

F'IGURE 8.-Planting fish in a trout stream on a national forest

public. Better roads, besides aiding in fire suppression, opening up new areas, and making possible better utilization of the material resources of the forests, have made it easier for the public to take advantage of the recreational resources. (Fig. 9.)

\section{FOREST VISITORS BRING BUSINESS TO THE REGION}

Outfitting, guiding, and managing parties of tourists through the more interesting portions of the national forests are becoming wellrecognized lines of business. On the Dixie National Forest in southern Utah are located the Cedar Breaks, a magnificent canyon head of red rock especially attractive to sightseers. Timpanogos Cave with its delicate formations in the Wasatch Forest, and the Kaibab National Forest, with its great herds of deer, the Uinta and Sawtooth Mountains, Fish Lake, the South Fork of the Payette River, etc., all appeal to many visitors. The "dude ranches" of Jackson Hole, surrounded by the Teton National Forest, are nationally known. The business connected with the recreational activities adds materially to the prosperity of the region. 


\section{DIRECT FINANCIAL CONTRIBUTION OF THE NATIONAL FORESTS TO THE COUNTIES}

Not only do the national forests contribute indirectly to the prosperity of nearly every county in the intermountain region; they also yield a good direct return each year in cash, a contribution that increases automatically as the utilization of forest resources increases.

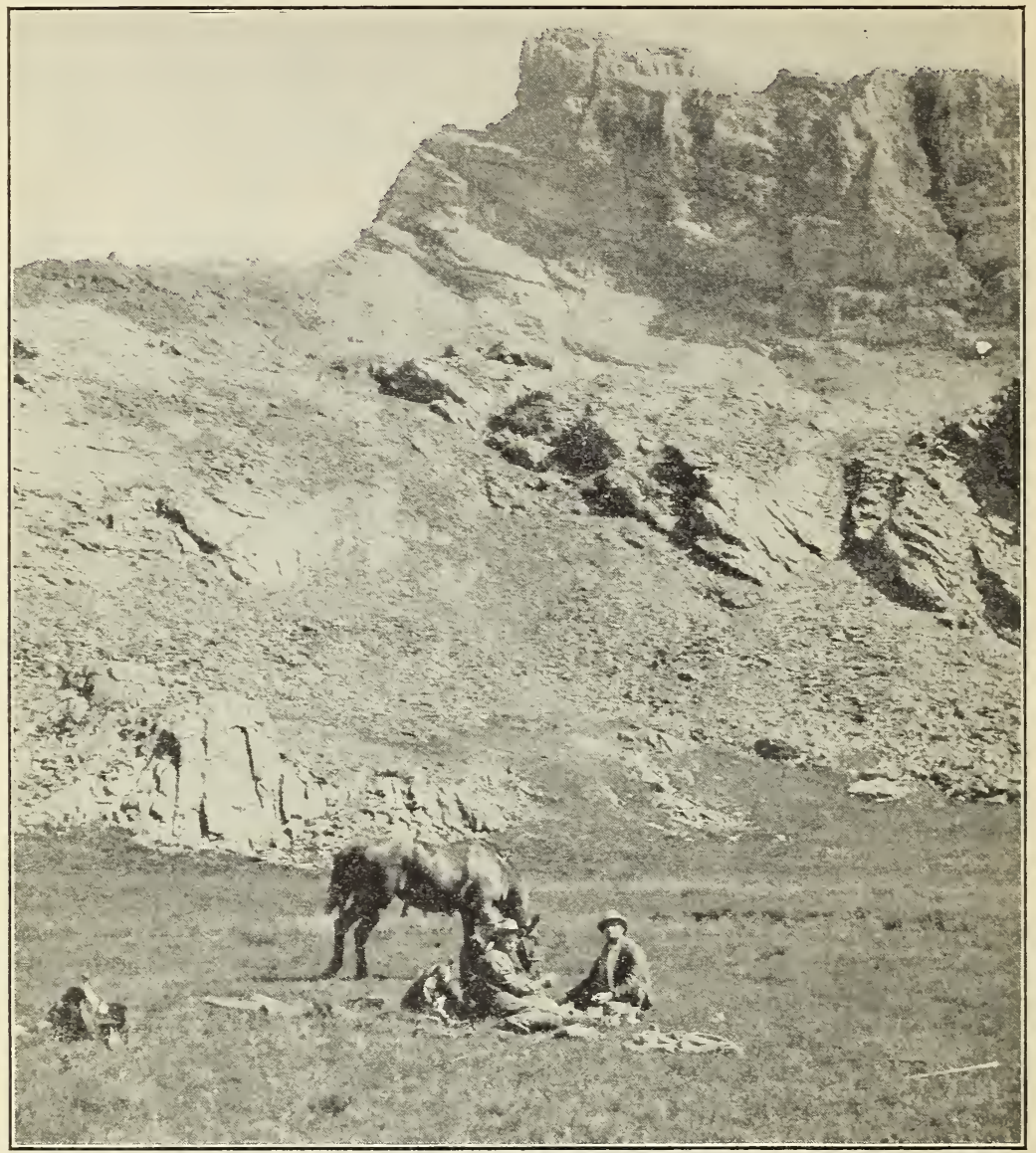

F-182623

FIGURE 9.-Enjoying the national forest near the summit of Mount Hyndman, the highest peak in Idaho (elevation 12,078 feet), on the Sawtooth-Lemhi Forest boundary

When the national forests were created and the lands embraced within them were removed forever from the tax rolls, Congress realized the burden that was thus imposed on the counties in which the national forests were located. In order to rectify matters it specified that 25 per cent of the gross receipts of the national forests should revert to the States for distribution among the counties in proportion to their national forest acreage, for the construction and maintenance of roads and for the support of schools. Thus, out of 
every dollar which the Forest Service takes in through the sale of national forest products, whether lumber or grazing, or by leasing land for special uses, 25 cents is returned to the county or counties in which the forest is situated. In the intermountain region the annual receipts from the national forests total about $\$ 657,000$ and accordingly some $\$ 164,000$ reverts to the different counties.

The counties receiving the largest contributions are, as a rule, not the richer but rather the sparsely settled and more remote counties, to which these receipts mean a great deal. In 1928 Custer County, Idaho, received over $\$ 7,000$ : Elko County, Nev., $\$ 11,700$; Fremont County, Wyo., $\$ 9,909$; and Valley County, Idaho, $\$ 14,600$. The protection and full utilization of national-forest resources means not only the prosperity of the counties adjacent to the national forests but greater direct returns to the county treasury for the improvement of roads and schools.

In addition to the 25 per cent already mentioned, another 10 per cent of the gross receipts from the national forests is spent by the Forest Service within the State in which it is collected to build and maintain roads and trails upon the national forests. Some of the most useful mountain roads in the intermountain region have been constructed from this so-called 10 per cent money. In Utah the road from Kamas to Stockmore across the Uinta Forest was financed by these funds, as well as a large part of the road from Ephraim to Orangeville, across the Manti Forest. In Idaho the road along the South Fork of the Payette River, which opens up an extensive and valuable forest region on the headwaters of the Payette, was financed by 10 per cent money. Anything, therefore, that increases the receipts of the national forests means an increase in road and trail building. This, in turn, means accessibility for the resources in the distant mountains and more pleasure for the recreationist. It also means greater efficiency on the part of the Forest Service in protecting these vast areas from fires and other possible destruction.

\section{WHAT THE PUBLIC CAN DO TO HELP PROTECT THE FORESTS}

\section{COOPERATION OF PRIVATE OWNERS}

Through well-considered regulation national forests are being brought to a high degree of usefulness in timber production, watershed protection, and utilization of grazing and other resources. There are, however, great areas of mountain lands in the intermountain region similar to the national-forest lands but not included within their boundaries. It remains, therefore, for the owners of such forest and mountain grazing lands as lie outside the national forests to assist in preserving and increasing the wealth of the region by applying to their lands such principles of forestry and range management as have proven valuable in their application to the national forests. Some owners are already doing this.

Arousing private owners not already alert is a desirable action in which all well-wishers of the forest can take part. Public opinion, properly fostered, will sooner or later crystallize into the hoped-for cooperation. The application of sound principles of management of mountain lands would not only increase the prosperity of the region 
and minimize the ever-present dangers that result from devastation of mountain lands, but would also aid in the application of these principles on adjoining national-forest lands and appreciably simplify many administrative problems.

\section{FIRE PREVENTION}

Especially urgent is the obligation resting on all national-forest users to exercise every precaution that will safeguard all the resources of the forest. This means, above all, being careful with fire. Such care is imperative, because the match or cigarette that seems to be out and the dead-looking camp fire sometimes start dangerous fires that may not be noticed until they have gained considerable headway. Of the average of 317 forest fires a year in the intermountain region, half are the result of human carelessness.

\section{DANGERS OF BRUSH FIRES}

Brush fires are not the harmless things many people consider them. Not only are they likely to extend to valuable timber, but they destroy watershed cover and in many instances hundreds of little trees not yet visible above the brush. They also destroy the scenic charm of the surroundings and form open spaces, which although small in extent are sometimes sufficient, with thunderstorms bursting upon them, to bring about disastrous floods in the small, steep canyons characteristic of this region.

\section{CARE OF CAMP GROUNDS}

Campers are especially urged to refrain from leaving trash or tin cans or anything that tends to deface the camp grounds or diminish the beauty of the surroundings. Hacking trees indiscriminately to obtain bed boughs should be avoided, as should also carving initials on trees, and everything that renders the forest less attractive to the next comer. As a matter of self-protection as well as out of consideration for others, the insanitary practices often indulged in by a thoughtless public should be discontinued.

\section{SUMMARY}

Though the prosperity of the intermountain region appears superficially to belong entirely to the valleys, it is to a remarkable extent derived from the forest-covered mountains. The development of the fur trade, irrigated farming, the lumber industry, the greater part of the livestock industry, the hydroelectric-power industry, and public recreation-the activities which contribute most to the prosperity and happiness of the intermountain region-are traceable directly to the wood, water, and forage supplied by the mountains; and the continuance of these activities, as well as their further development, necessitates the perpetuation of at least as much forest cover as the mountains now have.

Destroy this regetation, and though the mountains continue to stand there-bare masses of rock and earth-they will fail to perform their mission of contributing to the wealth of the region. 
In a semiarid climate, nature can heal wounds upon the mountains only slowly. In the meantime erosion and destruction go on more and more rapidly, so that the forces of reconstruction wage a losing fight against them. It is therefore imperative that forest visitors, private forest owners, and the general public cooperate wholeheartedly in working for the perpetuation of the intermountain forests. 


\section{ORGANIZATION OF THE UNITED STATES DEPARTMENT OF AGRICULTURE WHEN THIS PUBLICATION WAS LAST PRINTED}

Secretary of Agriculture Assistant Secretary

Director of Scientific Work

Director of Regulatory Work

Director of Extension Work

Director of Personnel and Business Adminis tration.

Director of Information

Solicitor

Weather Bureau

Bureau of Animal Industry

Bureau of Dairy Industry

Bureau of Plant Industry-

Forest Service

Bureau of Chemistry and Soils

Bureau of Entomology

Bureau of Biological Survey

Bureau of Public Roads.

Bureau of Agricultural Economics

Bureau of Home Economics.

Plant Quarantine and Control Administration.

Grain Futures Administration

Food and Drug Administration

Office of Experiment Stations

Office of Cooperative Extension Work

Library
ARTHur M. HYDE.

R. W. Dunlap.

A. F. Woods.

Walter G. Campbetl.

C. W. Warburton.

IV. W. STOCKBERGER.

M. S. EISENhoweR.

E. L. Marshall.

Charles F. Marvin, Chief.

JoHN R. MoHLER, Chief.

O. E. REeD, Chief.

William A. Taylor, Chief.

R. Y. Stuant, Chief.

H. G. KNIGHT, Chief.

C. L. MarlatT, Chief.

Paul G. Redington, Chief.

Thomas H. MacDonald, Chief.

Nils A. Olsen, Chief.

Loutse Stanley, Chief.

Lee A. Strong, Chief.

J. W. T. Duver, Chief.

Walter G. CAMPBelL, Director of

Regulatory Work, in Charge. , Chief.

C. B. Sмrтн, Chief.

Claribel R. Barnett, Librarian. 


$$
\text { , }
$$


